\title{
2. The Code of Good Practice on Referendums
}

\section{Pierre Garrone}

\section{INTRODUCTION}

The Venice Commission, the Council of Europe's body specialized in constitutional matters, is now 30 years old, and one of its main fields of activities has, nearly since the beginning, been electoral law - including legislation on referendums and political parties.

The Venice Commission has been made known by its opinions on constitutional and other major legislative reforms, but it may also count amongst its main successes the drafting of texts developing the major international standards deriving from the three main pillars of the Council of Europe: democracy, human rights and the rule of law.

A number of these texts have become reference texts of the Council of Europe, supported by its main bodies: the Committee of Ministers, the Parliamentary Assembly and the Congress of Local and Regional Authorities. This was the case in recent years with the Rule of Law Checklist. ${ }^{1}$ However, this had already been much the case previously with international standards in the field of elections and referendums, a field in which the Venice Commission is a pioneer in codification - after the United Nations Human Rights Committee, with its General Comment No. 25 of $1996{ }^{2}$

At the impulse of the Parliamentary Assembly, the Venice Commission thus adopted, in 2002, the Code of Good Practice in Electoral Matters. ${ }^{3}$ This document defines not only the fundamental standards of the European electoral heritage, which are universal, equal, free, secret and direct suffrage as well as frequency of elections, but also the framework conditions necessary for organ-

Study No. 711/2013, CDL-AD(2016)007.

2 General Comment No. 25: The right to participate in public affairs, voting rights and the right of equal access to public service (Art. 25), 12 July 1996, UN Doc. CCPR/C/21/Rev.1/Add.7.

3 Opinion No. 190/2002, CDL-AD(2002)023rev2-cor. 
izing proper elections, such as respect for human rights, particularly in the political field, organization of elections by an impartial body and an effective system of appeal and observation.

Due to the increased interest of the Assembly in the issue of referendums, the Venice Commission took the initiative to complement the Code of Good Practice in Electoral Matters by a counterpart specifically dedicated to referendums. This does not mean that there should not be common rules for both elections and referendums. On the contrary, the new document, the Code of Good Practice on Referendums ('Code'), ${ }^{4}$ begins by listing the principles of Europe's electoral heritage applicable to both elections and referendums (universal, equal, free and secret suffrage) and the conditions for implementing those principles (including respect for fundamental rights, stability of the law, organization of the ballot by an impartial body, existence of an effective system of appeal), while adapting them to the peculiarities of a referendum. It includes, however, a third part, which focuses on the specific rules applicable to the referendum only.

\section{CONTENTS OF THE CODE}

According to the Code's third part, entitled 'Specific Rules', the three main principles to be followed are:

- Respect for the rules of procedure in the call for referendums;

- Respect of procedural standards by the text submitted to a referendum;

- Respect of superior law by the text submitted to a referendum.

Respect for the rules of procedure in the call for referendums is dealt with first under the title 'the rule of law', which states:

The use of referendums must comply with the legal system as a whole, and especially the procedural rules. In particular, referendums cannot be held if the Constitution or a statute in conformity with the Constitution does not provide for them, for example where the text submitted to a referendum is a matter for Parliament's exclusive jurisdiction. ${ }^{5}$

In other words, the call for a referendum must, first of all, comply with the law, including procedural rules which may - misleadingly - look technical and secondary. What ensures that the vote is the expression of the free will of the people is respect for these procedural rules - if they are themselves in conformity with the principle of free suffrage.

Study No. 371/2006, CDL-AD(2007)008rev-cor.

Code, III.1. 
It is not rare that national rules of procedure are violated - such as through the use of referendums outside of the field in which they are authorized by law. This can lead to referendums on secession in contravention of the national constitution, ${ }^{6}$ but also to less visible violations, such as a referendum intended to revise directly a constitution which does not provide for such a mode of revision ${ }^{7}$ or a referendum on an issue, or on the initiative of an authority, not mentioned by the constitution. ${ }^{8}$

It is not only the call for a referendum, but also its context, which must respect superior law, including constitutional and international standards. Respect for fundamental rights, in particular freedom of expression and of the press, freedom of movement inside the country, freedom of assembly and freedom of association for political purposes, including freedom to set up political parties, is also essential to ensure democratic referendums. ${ }^{9}$

The second main principle to be followed is respect of procedural standards by the text submitted to a referendum, which is meant to guarantee free suffrage.

Some of these procedural standards are elements of the general freedom of voters to form an opinion that are applied, mutatis mutandis, to referendums. They include, first, the requirement that administrative authorities must be neutral. While this requirement is not as stringent as in the case of elections, administrative authorities must not influence the outcome of the vote by excessive, one-sided campaigning, and the use of public funds by the authorities for campaigning purposes must be prohibited. ${ }^{10}$ Second, authorities are required to provide objective information. ${ }^{11}$

Other standards address issues which are marginal in the electoral field but central for referendums. Thus, the Code states, first, that ' $[\mathrm{t}]$ he question put to the vote must be clear; it must not be misleading; it must not suggest an answer; voters must be informed of the effects of the referendum; they must be able to answer the questions asked solely by yes, no or a blank vote. ${ }^{12}$ In

6 Opinion on 'Whether the Decision Taken by the Supreme Council of the Autonomous Republic of Crimea in Ukraine to Organise a Referendum on Becoming a Constituent Territory of the Russian Federation or Restoring Crimea's 1992 Constitution Is Compatible With Constitutional Principles', Opinion No. 762/2014, CDL-AD(2014)002; Letter by the President of the Venice Commission to the President of Catalonia, Spain, 2 June 2017.

7 Opinion on the Constitutional Referendum in Ukraine, 31 March 2000, CDL-INF(2000)011.

Press release of 15 March 2010 (Republic of Moldova).

Code, II.1.

10 Code, I.3.1 a-b.

11 Code, I.3.1 d.

12 Code, I.3.1 c. 
elections, on the other hand, it is sufficient to know who the candidates are and for which party they run. Second, the effects of the referendum must be clearly specified in the constitution or by law. ${ }^{13}$ Although also electoral systems might not always be easily understandable, this question is even more crucial for referendums, especially given that some of them are not legally binding, but consultative.

Finally, some principles have no equivalent in the field of elections, namely those relating to the 'procedural validity of texts submitted to a referendum'. ${ }^{14}$ According to the Code, questions submitted to a referendum must respect the requirements of unity of content, unity of form and unity of hierarchical level. Unity of content means that, except in the case of a total revision of a text, there must be an intrinsic connection between the various parts of each question put to the vote. Voters should not be compelled to accept or reject proposals as a bloc which are not interrelated. Unity of form means that the same question must not combine a specifically worded draft amendment with a generally worded proposal or a question of principle. The reasons for this requirement are set out in the explanatory memorandum to the Code as follows:

A 'yes' vote on a specifically-worded draft - at least in the case of a legally binding referendum - means a statute is enacted and the procedure comes to an end, subject to procedural aspects such as publication and promulgation. On the other hand, a 'yes' vote on a question of principle or a generally-worded proposal is simply a stage, which will be followed by the drafting and subsequent enactment of a statute. Combining a specifically-worded draft with a generally-worded proposal or a question of principle would create confusion, preventing electors from being informed of the impact of their votes and thereby prejudicing their free suffrage. ${ }^{15}$

In other words, the purpose of the requirement is to prevent confusion and thus guarantee free suffrage. The requirement of unity of hierarchical level, finally, is equally intended to protect the voter's free expression of his or her will, although it might be less central. It implies that the same question should not simultaneously apply to legislation of different hierarchical levels, for example the constitution and ordinary legislation.

The third main principle concerns the substantive validity of the text submitted to a referendum. The Code provides that ' $[\mathrm{t}] \mathrm{exts}$ submitted to a referendum must comply with all superior law (principle of the hierarchy of norms). They must not be contrary to international law or to the Council of Europe's statutory principles (democracy, human rights and the rule of law).' ${ }^{16}$

\footnotetext{
Code, III.8.

Code, III.2.

Explanatory memorandum, para. 29.

16 Code, III.3.
} 
These are general principles which apply whatever the internal mechanisms of control of conformity with superior law are, and irrespective of what national law has to say about the relationship between international law and domestic law. Like the requirement of conformity of the call for referendums with superior law, they are the expression of the more general principle of legality, which includes the requirement of conformity of legislation with the constitution, ${ }^{17}$ but also the principle pacta sunt servanda, which is the way in which international law expresses the principle of legality. ${ }^{18}$ The reference to the Council of Europe's statutory principles evokes more general international commitments of European states. These core values are interrelated; referendums - like elections - would be meaningless in their absence ${ }^{19}$ and should not destroy the principles they are based on..$^{20}$

The sanction in case of violation of the principles detailed above (call for the referendum in conformity with the law, procedural and substantive validity of the texts submitted to a referendum) should be that the text is not submitted to the popular vote. ${ }^{21}$ In order to avoid declaring total invalidity, however, 'an authority must have the power ... when rules on procedural or substantive validity have been violated ... [to declare] partial invalidity ... if the remaining text is coherent'. ${ }^{22}$ If the referendum nevertheless went ahead, this would be a serious irregularity implying its annulment. ${ }^{23}$

Direct democracy is not a substitute to representative democracy. It should not be a way to exclude parliament from the process, in particular when the referendum is initiated by the executive, but also in case of a popular initiative. Therefore,

[w] hen a text is put to the vote at the request of a section of the electorate or an authority other than Parliament, Parliament must be able to give a non-binding opinion on the text put to the vote. In the case of the popular initiatives, it may be entitled to put forward a counter-proposal to the proposed text, which will be put to the popular vote at the same time. ${ }^{24}$

On the other hand, parliamentary procedures should not be used to circumvent decisions taken by a binding referendum. ${ }^{25}$

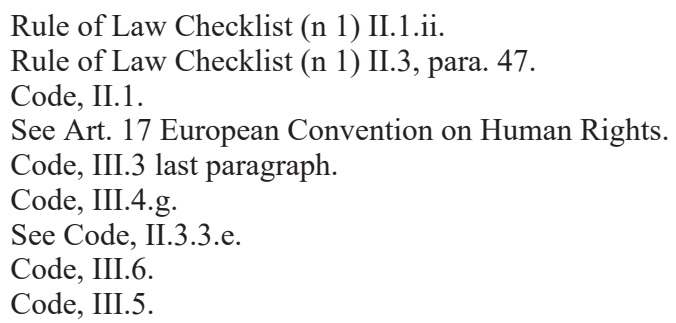


Finally, the Code makes it clear that it disfavours quorums. A turnout quorum should be avoided, according to the Code, 'because it assimilates voters who abstain to those who vote no'. An approval quorum (requiring approval by a minimum percentage of registered voters), in turn, 'risks involving a difficult political situation if the draft is adopted by a simple majority lower than the necessary threshold'. ${ }^{26}$

\section{USE OF THE CODE}

It must be noted that the Code is a reference text of the Council of Europe as it was not only adopted by the Venice Commission after approval by the Council for Democratic Elections - a tripartite body including members of the Venice Commission, the Parliamentary Assembly and the Congress of Local and Regional Authorities of the Council of Europe - but also endorsed by the plenary sessions of the Assembly and the Congress. The Committee of Ministers, for its part, adopted a Declaration on the Code of Good Practice on Referendums for the purpose of inviting public authorities in the member states to be guided by it.

What is, then, the use of the Code in practice? The Venice Commission quotes it regularly in its opinions and reports in the field, and this leads states to discuss the conformity of their legislation with its standards in the framework of the preparation of the Venice Commission's opinions. This has been true since the Code's adoption in 2007, both for joint opinions with the OSCE/ ODIHR as well as for those drafted by the Venice Commission alone. ${ }^{27}$ The formula, which by now has become traditional, is as follows:

The ensuing recommendations are based on relevant Council of Europe and other international human rights standards and obligations, OSCE commitments, and good international practices. In particular, they are based on the reference document of the Council of Europe in the field, the Code of Good Practice on Referendums drafted by the Venice Commission. ${ }^{28}$

26 Code, III.7.

27 See, as a first example, the Joint Opinion on the Electoral Code of Moldova as of 27 March, 2007, Opinion No. 455/2007, CDL-AD(2007)040, fn 20; and, more recently, Armenia - Joint Opinion on the Draft Law on Referendum, Opinion No. 844/2016, CDL-AD(2017)029, passim.

28 Joint Opinion on the Electoral Code of Moldova (n 27), para. 13 (emphasis added); see also Turkey - Opinion on the amendments to the Constitution adopted by the Grand National Assembly on 21 January 2017 and to be submitted to a National Referendum on 16 April 2017, Opinion No. 875/2017, CDL-AD(2017)005, para. 32; Opinion on the Citizens' bill on the regulation of public participation, citizens' bills, referendums and popular initiatives and amendments to the Provincial 
While opinions relating to specific legislation on referendums regularly refer to the Code, the Commission has other opportunities to quote it when dealing with referendum issues in the assessment of a broader piece of legislation or when drafting general reports.

A number of these quotations refer to the issue of quorums. As mentioned above, the Code is not in favour of quorums. However, the formulation it uses ('it is advisable not to provide for ...') is not too strict. ${ }^{29}$ This has led the Commission to take account of specific circumstances. It recommended to the Republic of Moldova ${ }^{30}$ and to Serbia ${ }^{31}$ not to provide for quorums. However, the Commission has specified that the Code is intended as applying to texts submitted to a referendum, defined as a specifically worded draft, repeal of an existing provision, a question of principle or a generally worded proposal, 'and not to the institution of the recall, which puts into question the elected body itself rather than an act it adopted'. ${ }^{32}$

Other references concern respect for the rule of law in the call for a referendum. The Commission has made it clear that referendums may not be held if they contravene the constitution ${ }^{33}$ or 'to undermine a constitutionally mandated division of powers'. ${ }^{34}$ Furthermore, a referendum should not be used as a means of settling a dispute between state institutions; accordingly, it would be more appropriate to submit to a referendum, rather than the question

Electoral Law of the Autonomous Province of Trento (Italy), Opinion No. 797/2014, CDL-AD(2015)009, para. 5.

29 Code, III.7.

30 Joint Opinion on the Electoral Code of Moldova (n 27), fn 20; Joint Opinion on the Election Code of Moldova as of 10 April 2008, Opinion No. 484/2008, CDL-AD(2008)022, para. 86; in the Joint Opinion on the Draft Working Text amending the Election Code of Moldova, Opinion No. 576/2010, CDL-AD(2010)014, para. 58, it stated, however, that 'turnout requirements may be acceptable in specific circumstances'.

31 Opinion on the Draft Law on Referendum and Civil Initiative of Serbia, Opinion No. 551/2009, CDL-AD(2010)006, para. 38.

32 Report on the recall of mayors and local elected representatives, Opinion No. 910/2017, CDL-AD(2019)011rev, para. 110; see also Opinion on a Draft Constitutional Law on the Amendments to the Constitution of Georgia, Opinion No. 519/2009, CDL-AD(2009)030, para. 16.

33 Opinion on 'Whether the decision taken by the Supreme Council of the Autonomous Republic of Crimea in Ukraine to organise a referendum on becoming a constituent territory of the Russian Federation or restoring Crimea's 1992 Constitution is compatible with constitutional principles' (n 6) para. 24.

34 Opinion on the law on national referendum of Ukraine, Opinion No. 705/2012, CDL-AD(2013)017), para. 18. 
of the dissolution of parliament, the respective legal text whose non-adoption by parliament gave rise to a conflict with the president..$^{35}$

The issue of freedom of voters to form an opinion ${ }^{36}$ has also been addressed in several opinions of the Venice Commission. This freedom implies, for example, that 'the referendum should not be used as a tool to bypass the legislators or force parliaments to adopt constitutional amendments quickly. Referendums gain legitimacy when carried out within a reasonable time frame. ${ }^{37}$ The Commission has also insisted on the clarity of the referendum question $^{38}$ and balanced coverage by the media of referendum campaigns. ${ }^{39}$

\section{CONCLUSION}

In short, the Code of Good Practice on Referendums, as the reference document of the Council of Europe in the field, details the standards which make possible the organization of democratic referendums in states based on the rule of law and respect for human rights. These standards are, mutatis mutandis, those applying to elections, but include also specific aspects proper to referendums. The Venice Commission and OSCE/ODIHR recall regularly their importance when addressing legislation on referendums in their opinions and reports, which has, in turn, led states to refer to them when preparing such legislation.

35 Opinion on a Draft Constitutional Law on the Amendments to the Constitution of Georgia (n 32), para. 16-17.

36 Code, II.3.1.

37 Peru - Opinion on linking constitutional amendments to the question of confidence, Opinion No. 964/2019, CDL-AD(2019)022, para. 38; see also already Azerbaijan - Opinion on the draft modifications to the Constitution submitted to the Referendum of 26 September 2016, Opinion No. 864/2016, CDL-AD(2016)029, para. 8 .

38 Opinion on 'Whether the decision taken by the Supreme Council of the Autonomous Republic of Crimea in Ukraine to organise a referendum on becoming a constituent territory of the Russian Federation or restoring Crimea's 1992 Constitution is compatible with constitutional principles' (n 6) para. 23.

39 Opinion on the law on national referendum of Ukraine (n 34), para. 32, 48. 